\title{
worldview
}

A JOURNAL OF RELIGION AND INTERNATIONAL AFFAIRS

SEIECTIVE CONSCIENTIOUS OBJECTION

STAUGHTON IYND

EVERETT E. GENDIER

PAUL RAMSEY

IHE NUCLEAR OBSESSION:

III. NONPROLFERATION AND

CHINA POLICY

JACK WALKER

VIEWS ON THE U.N.

JOHN R. INMAN

FEBRUARY

$\overline{1967 \quad \text { VOL. } 10 \quad \text { NO. } 2}$

\section{SELECTIVE SERVICE AND SELECTIVE OBJECTION}

As the war continues and the demand for men mounts, the deficiencies of the present Selective Service and Training Act come under increasing attack. One of the most difficult problems for the Presidential Commission, Congressional panels and, indeed, for anyone who considers it carefully, is that posed by the non-pacifist who believes that he cannot conscientiously bear arms in the present war - the selective conscientious objector or the particular war objector, as he is variously known.

There are many people who will immediately be offended at the idea that young men are willing to pit their individual judgment against the full authority of the government in matters so complex. As one columnist put it, to let youngsters decide whether a particular war was just or not would be "a helluva way to run a railroad." But faced with the same problem Lt. General Lewis B. Hershey gave a different response. When asked what he would do if he were of draft age and forced to perform military acts he found it morally impossible to support, he is reported to have said, "In order to maintain your dignity you'd have to go to the penitentiary."

Those who advocate draft exemption for the selective conscientious objector believe that he should be able to maintain his dignity without going to jail, that to impose the choice of being a soldier with a violated conscience or a prisoner with a free conscience is to impose harsh and unfair alternatives. Among those who advocate this change are various Peace Fellowships, the American Civil Liberties Union and a number of prominent religious leaders. But the greatest pressure, naturally and inevitably, comes from those young men facing the draft who are positing conscientious objection to the war in Vietnam as their position.

The issue is important, tough and immediate. It deserves consideration now. For these reasons most of this issue of worldview is devoted to a consideration of a small part of a statement that Freedom House recently placed in the New York Times. Among the 145 prominent people who signed the statement were Dwight D. Eisenhower, Dean Acheson, James B. Conant, Thurston N. Davis, S.J., Will Herberg, Jacob K. 
Javits, S. L. A. Marshall, Paul Ramsey, Elmo Roper, Donald C. Stone, Eustace Seligman and Henry P. Van Dusen.

Calling upon "responsible critics of the Vietnam war to dissociate themselves from wild charges;" the statement listed a number of current objectionable "fantasies," one of which concerned military service and the moral discretion of the individual. As it appeared in the statement, the "fantasy" was presented briefly with little development or qualification: "That military service in this country's armed forces is an option exercised solely at the discretion of the individual." Before this can be reasonably accepted or rejected as fantasy, the statement itself needs development and elaboration. A number of people fron different professional and political backgrounds were, therefore, asked by worldview to provide that development and state their own judgments.

These commentators do not agree on all of the major issues which they consider; they may even fail to convince a number of readers that the issues are major. But those who are open to persuasion or who simply find their own beliefs here reiterated - will grant that the problem merits consideration by all citizens and particularly by those who bear most immediate responsibility for shaping the draft laws of our country.

J. F.

\section{in the magazines}

Contritutors to this issue of teorldview examine one of five "fantasies" from which Freedom Honse urges responsitble critics of the Vietnam war to dissociate themsclves. All five points are reviewed by Hans Morgenthat in an article written for the New Leader (January 2). He notes "the document declares that failure by the responsible critics of our Vietram policy to draw the line botween their positions and the vieus expressed by irresponsible extremists could encourage our Communist adversurics to postpone serious negotiations, raising the cost in lives and delaying the peace we earrestly scek.' In other words, the blood of our. men who must die in Vietnam is in the hands of the "irresponsible' opponents. This charge," Morgenthau states, "derives from the assumption that the policies of our Vietnamese adversaries are determined by what some Americans may or may not say abolit the policies of their tovernment. This is an extraordinary view of the policy-making processes of any government, past or present. I would have thought ... that a goveriment engaged in war will be infuenced in its attitude toward peace by its estimate of the military situation and of the peace terms it thinks it can obtain. As long as it thinks it can win, or can get better peace terms by continuing the war, it will go on fighting; when it thinks it is likely to lose, or has nothing to gain from continuing the war, it will stop fighting."

And further; "The Freedom House document, in spite of a ritualistic bow to free speech, effectively limits frce speech. It distinguishes between the argu- ments against our policies in Vietnam that are legitimate and those that are not... .

"The Frecdom House document is trying to establish a political orthodoxy with regard to our policies in Vietnam. It tells us that we are morally entitled to criticize the government, but not with regard to the fundamental issucs it enumerates. . . .

"The document condemns the holders of certain opinions as being responsible for the continuation of the var in Vietnam. I hold these opinions. ..."

In replying to Dr. Morgenthau (issue of January 16 , the chairman of the executive committee of Frcedom House, Leo Cheme, notes that the document's 